\title{
Exploring the Strategies Proposed by Quran and Psychology for Dealing with Despairs
}

\section{Maryam Hojjat Farsangi}

PhD student in Quran and Hadith Studies, Ferdowsi University of Mashhad, International Campus

Hassan Naghi Zadeh

Corresponding Author, Associate Professor, Faculty of Theology, Ferdowsi University of Mashhad

Mohammad Saeed AbdKhodayi

Associate Professor, Faculty of Education and Psychology, Ferdowsi University of Mashhad

Mohammad Ali Rezayi Kermani

Associate Professor, Faculty of Theology, Ferdowsi University of Mashhad

\section{Doi:10.5901/mjss.2016.v7n3s3p28}

\section{Abstract}

The material world is the arena of interference and restrictions. That's why men always encounter sufferings, deprivations, and frustrations on the one hand, and joy and prosperity on the other hand. The Quran also confirms that human life is accompanied with suffering, (Balad, 4) so bitterness and "stress" is an integral part of human life. We should explore the ways to deal with these despairs and preserve our mental balance in happiness and sadness. In the light of the guidelines of Holy Quran which discusses this matter in multiple verses, it is possible to analyze the right and wrong ways of dealing with the events. Psychology also suggests ways to cope with the difficulties. Having investigated the strategies proposed by Quran and Psychology, the survey is to compare the resulting solutions and findings show that Holy Quran, according to cognitive restructuring based on God-centered worldview, offers better ways to retain human's balance in despairs and prosperities.

Keywords: difficulties, happiness, sadness, excitement, coping strategies

\section{Introduction}

In this study, we sought to answer the question 'what are the Qur'anic and Psychological strategies for coping with difficulties in life? How can we maintain our mental balance in happiness and sadness?

Since the time human beings came to earth, the suffering and the pain were his constant companions. He found the bitterness of failures associated with sweetness of successes and that life without suffering is an unattainable dream. Pain and suffering are more in human beings than in other creatures (since man was created weak! 4/ 28). From uterus to birth and birth to death, human being is faced with many world disasters. (Tayeb, Sayed Abdul Hussain, 1999, vol 14, p 118)

Difficulties and evils are inherent in the nature. Sins and evils are of two types: they are either non-existent like the lack of existence and the lack of grace, such as poverty, ignorance, impotence... or existent which are created due to some given reasons, such as flood, earthquake, war and etc.

In the first case where the unfortunate phenomenon is non-existent, there is no entity and existence to be attributed to God or every entity other than Him, because absence and loss do not need any reason and agent to be discussed.Indeed, the question raised in this category is why the special grace of God has been cut off? And it may be concluded that human's evil deeds can be the cause of his deprivation of God' blessings. In the second case, events include two elements of "existence" and "evil". By existence, the events are attributed to God and by evil they are ascribed to humans, because the existence equals good, and disastrous accidents regardless of their titles and the calamity they caused to the society, can be contingent existent, and each contingent existent, mediated or unmediated, ends in the necessary being that is self- efficient. Therefore, the existence of this kind of sins and evil deeds, like sweet events and good deeds, originates from God, ( Everything comes from God4/78 )and everything given by God is the 
grace and blessing, but human turns it into evil due to inappropriate use of it. Due to not building a dam or proper harassment of the rain, the mercy converts to a destructive flooding or nutritious food may cause weakness and disease because of overeating or having a wrong diet (Javadi Amoli, Abdollah., 2004, p. 407)

The existence of evil is a relative thing, not something real. That is, every evil such as death, poverty and evil that can be perceived in the world is evil in relation to itself and good with regard tothe others, especially to the collective and general system that exists in the world. So when it is said that something is good, it means that God has done favor tothe thing itself and the evilness of the evil also shows that God intends to benefit the others andit may happen that the grace of God primarily has causeddeficit or death, and so on. A variety of deficiencies, slippages and flaws in the creatures result from the deficiency in the capacities of material things. The lack of grace is not originated from God, but from incapability of the creatures that make them unqualified to be given such a grace. (Tabatabai, Muhammad Hossein, 1417, vol 17, $p$ 403) no creature is evil in itself, rather the evil is a condition that occurs when two things are compared. Snake and scorpions' venoms are the sources of their evolution and survival and compatible with their integrity and since they cause human some damage, they appear to be "evil". In addition, many evils such as wars and murders arise by humans. Some evils are also the result of human actions which are contrary to human dignity of creation and reflect back to the human himself. (Motahari, Morteza, 1982, p. 151)

Holy Quran also attributes the goodness to God and the evil to human. (Any good that happens to you comes from God, while anything bad that happens to you is through yourself. We have sent you as a Messenger to[ instruct ]mankind; and God suffices as a Witness 4/,79)

Calamities and disasters that appear to man are God's favor to him and provide him the opportunity to repent on the one hand (An'am, 42) and on the other causes his growth. In this regard, Imam Khomeini says:

"Being submerged in pleasures and desires leads to the love of the world, which in turn results in the hatred of every things other than the world. If a man suffers from something, and experiences the adversities, the experience creates a kind of hatred in him. The stronger this perception, the stronger will be the feeling of hatred. If one enters a city where he is afflicted by internal and external adversities and diseases, he would abhor the city, and if there is a better city, he would move there, otherwise, he would get interested in that city and move his heart there. A human who has suffered from the world disasters, he would hate it and his attachment to it would decrease. It is also clear that moral and spiritual ills result from the attachment to the world and the neglect of God and Hereafter. That is why God's grace and favor are more granted to those who turn away from the world and its pleasures. "(Khomeini, Ruhollah, 1989, p. 207)

Now that the existence of evil and suffering is intertwined with human lives, the strategies of dealing properly with these failures and despairs should be examined.

In this study, the strategies proposed by Holy Quran on how to deal with failures are at first reviewed, then psychological views are investigated, after that the two are compared and in the end, the logic of Islam in preserving the mental balance in happiness and sadness is studied.

\section{Research Literature and Methodology}

Numerous articles have been written on how to deal with stress according to Psychology, the ways to cope with the difficulties from the perspective of Nahjul Balagha, and the sadness and happiness in Islam; however, no study has been done on the comparative study of the strategies introduced by Quran and psychology for coping with the difficulties.

The desk research method is used in the study and reference is made to the interpretation of Quran's verses and traditions and the psychological resources.

\subsection{Inappropriate approach to despair and prosperity}

In multiple verses, Holy Quran criticizes the inappropriate strategies applied by untrained people to deal with difficulties. In fact, this criticism can be assigned to people' attitude and behavior:

1- Incorrect behavior: pride and rebellion in blessings, and moan, impatience and prayer indifficulties.

Whenever We show man some favor, he spurns it and drifts off to one side. Then when any evil afflicts him, he appeals[ to Us ]both loud and long (41/51) "Naya: turn aside" means pulling away that implies arrogance and pride: he turns his face away like the arrogant. The "lengthy supplication" also alludes to a lot of prayer. Because of his pride, human being becomes disappointed and resorts to pray when incapable to ward off the evil. And when in blessings, he becomes so proud that the same blessing prevents himto see the truth (Tabatabai, Muhammad Hossein, 1417, vol 17, $p$ 612)

In Chapter Ma'arij, the mismanagement of the self and the reasons are explained as follow: 
Man has been created restless, so he panics whenever any evil touches him, and withdraws when some good touches him(70/19-21)

This attribution of greediness to human being on one hand and the denouncement of the quality on the other hand have caused disagreement among exegetes. Zamakhshari believes that there is a metaphor in the verse. Given that one in practice always prefers moaning to being patient,it seems that moaning is not an optional trait, but an innate one in human. However, if it is so, God should not condemn it. (Zamakhshary, Mahmoud, 1407, vol. 4, p. 612)

Allameh Tabatabai believes that man is created in the divine wisdom greedy in order to be led to what is good. Human nature is characterized by being greedy to seek his own advantages and interests. This innate greed is one of minutiae of self-lovebut it's not regarded to be a vice. However, if not appropriately planned, it becomes a vice. A child indicates an extreme greed on what he thinks is good for him, but once equipped with intellect, he would know the true good and indicate a greed for the true good that is the obedience to God and the hereafter and would be always thirsty for good deeds. But if he turns away mentally from the intellect, commits to his passion as he was in his childhood, shows greed for mundane issues and does not manage it, the instinctive trait turns into a moral vice. (Tabatabai, Muhammad Hossein., 1417, vol. 20, p. 17) This explanation seems more reasonable because any sensual trait in human nature needs to be managed and moderated, otherwise it will become a vice. Self-love, instinct and rage.... All are of this kind of traits. God also criticizes human'smisbehavior in difficulties and blessings: Whenever any trouble afflicts a man, he appeals to his Lord, showing his concern for Him; then when He confers some favor on him from Himself, he forgets what he had already been appealing to Him about, and sets up rivals for God so he may mislead[ people ]from His way. SAY:" Enjoy your disbelief for a little while; you will[ soon ]be an inmate of the Fire!"( 39/8 )

Acknowledging the Lordship of God, the man afflicted by distress calls upon Him, turns away from whomever other than Him and asks Him to solve his problem. However, once his plight was relieved and a blessing came to him, he forgets God.

The mismanagement of self makes human despaired in the face ofdifficulties. Whenever We show man some favor, he avoids it and drifts off to one side; while whenever evil touches him, he acts desperate.( 17/83)

Someone who does not believe the role of God in the affairs, will be disappointed when sees they stop and do not work (Tabatabai, M.H, 417, vol. 13, p. 185)

Besides forgetting God, arrogance and turning away from Him, there are a group of people- cited in Surah Nahl who read out God with crying and moaning when an evil befalls them, but associate the others with God when they are favored by blessings: You will receive no favor unless it comes from God. Yet whenever some harm touches you, you plead with Him;then when He removes the harm from you, why a group of you will associate( others )with your Lord,(16/53- 54 )

2. The wrong attitude: indifference to the philosophy behind the blessings and curses

Holy Quran, in many verses, refers to people who do not understand the educational role of difficulties and have a wrong interpretation of events:

Yet everyman says, whenever his Lord tests him by honoring and favoring him:" My Lord has honored me!";while whenever He tests him by rationing His sustenance for him, he says:" My Lord has disgraced me."( 89/15-16 )

"Al" in "Al- Ensan"indicates species not inclusion, and includes all human beings. Since he regards his God's blessings as respect, human being gives himself the right to do whatever he likes, to mount rebellion and corruption. If not blessed by God, he thinks God is his enemy. Therefore, he begins to moan and becomes infidel. (Tabatabai, Muhammad Hossein, 1417, vol 20, p 282)

The Quran cites Korah (Qarun) who attributes his great wealth to his knowledge and wisdom: (He said: "I have been given it only because of some knowledge I possess 28/78 )

The feature does not belong solely to Korah and it seems that all immature people attribute the blessings of God to their own merits, and disregard the role of the Lord:

Whenever any trouble afflicts man, he appeals to Us; then when We confer some favor from Ourself on him, he says:" I was given it only because I knew[ enough ]."( 39/49)

It is this wrong attitude and misconception that causes human arrogance and stubbornness in blessings and his despair in curses.

\subsection{The appropriate approach to despair and prosperity}

The beautiful true picture God provides of a human trained in the school of revelation is a man who has a right attitude towards the creation, manages his self in all circumstances and preserves his mental balance in welfare and deprivation. It seems to be the educational philosophy behind problems and God' trials: 
so that you should not feel sorry about what may have escaped you, nor yet rejoice in what He has given you. God does not love every conceited boaster( $57 /-23$ )

In this verse, favors are gifts given by The Lord and are attributed to Him (Atakom). However, as any creature is mortal, mortality needs no reason and therefore is not attributed to God (what escape you: Mafatekom). According to Holy Quran, human arrogance is rooted in his pride. A proud person is one who views what he has as his virtue and therefore is proud of himself. Arrogance derives from the illusion that human being deserves such blessings, because he attributes to himself what he should associate to God (Tabatabai, Muhammad Hossein., 1417, vol 19, p 166). "Rejoice: farah" in this verse is a kind of joy that makes his owner rebellious and ungrateful, however, pleasure, wrath and grief are found in human nature and cannot be prohibited. What can be prohibited is the pleasure and grief's requirements and preliminaries or their consequences that include ingratitude to God and moan. (Zuhayli, Wahbabin Mustafa, 1418, vol. 27, p. 327). Imam Ali regards the verse to be the interpretation of piety:

"Piety is mentioned in two verses of Quran. Glorified God says: "do not regret what you have lost and do not rejoice what you are given". One who does not regret the past and does not rejoice his achievements, is a truly Piet." (Hekmat 431)

\section{Quran's Strategies for Dealing with Despairs}

\subsection{The change of attitude}

Through changing human's attitudes and worldview, Quran trains human so that,first of all, he attributes all the blessings to God, is pleased with the fate He has determined for him and puts his trust in Him. With words such as "Atakom" (Hadid, 23), "Rahmatan menna: (Hood, 9), "Nematan menna:" (Az-Zumar, 8) (Az-Zumar, 49) "Nematan: blessing" (Dawn, 15), God reminds us that all blessings are from Him, therefore there is no place for arrogance, turning away from God, oblivion and infidelity. Ali considers his life as the result of satisfaction with the divine destiny. (TamimiAmoudi, Abdul Wahid, 1410, p. 270) Imam Sadiq sees the convenience and comfort in "certitude and satisfaction" and sadness and sorrow in "doubt and wrath". (Kulaini Muhammad bin Yaqoob, 1429, vol. 2, p. 57)

Secondly, he notifies people that the world favors are short-lived and do not last all over the life of human. Quran uses words "massa" or "azaga" in different verses to refer to the occurrence of a blessings or hardships of the world. "massa" and "Azaqa" means touching and tasting respectively. This interpretation suggests that the sweetness or bitterness of the world is as short-lived as tasting or touching. When human realizes the world's nature (An'am, 32),he would not be attached to it and the divine blessings' coming and going make no change in his heart. Believers regard themselves to be God's trustee, as treasury officials who get one day a large amount of property and pay thousands another day. Therefore, they become neither happy for receiving nor sad for paying it. (Makarem Shirazi, Naser, 1992, vol 23, p 366)

According to Imam Ali, if people know the world, they would not be caught in grief. (Tamimi Amoudi, Abdul Wahid, 1314, p. 649) Imam Ali introduces the world as:

"The world consists of two days: one day is to your benefit and the other day is against you, so do not rejoice when it benefits you and be patient when it causes a loss to you." (a 72)

The believer should ever know the nature of the world in order to gain peace and stability; otherwise, he could not achieve his goals. Poverty and wealth, disease and healing, weakness and strength and victory and defeat happen to human. How is the mental balance created? First, the knowledge of the world nature and the attachment to God that lead to the piety causing human to be neither extremely happy when he is favored, nor extraordinary sad when he faces difficulties. Second, satisfaction with the fate that God determined for us is the highest degree of piety and faith. To believe in fate prevents pride in the happiness and despair in sadness. Despair deprives the human of the agency and mobility, but why despairs? Calamity results from either the will of God for which there is no choice except confession and submission to it, or from we ourselves, but in this case that we are able to resist change there is no room for despair. Joy and vanity both halt us and sometimes lead to idolatry. (Modarresi, Seyed Muhammad Taghi, 1419, vol. 15, p. 87).

In a letter to Ibn Abbas, Imam Ali writes: "People become glad because of achieving what they would not lose (even if they do not rejoice, they would achieve it) and become sad due to losing what they likes, despite all attempts they make. Then you should be happy with the decent work and good judgment you have done and regret those things you have neglected. So, leave those things you have lost and don't moan on them, don't rejoice in the things the world would come to you and be worried about your state after death in Hereafter. "(Kulaini, Muhammad bin Yagoob, 1429, vol. 8, p. 240)

Imam Ali also defines the pious person as: 
"People are of three kinds: Piet, patient and willing ( for the world), the Piet is a person who neither rejoices in what he obtains nor laments for what he has lost, so he is relieved. "(Culaini, Muhammad ibn Yaqoob, 1429, vol. 2, p. 456) This was due to this piety that Mūsa ibn Ja'far did no regret being in Baghdad dark prison and Solomon hadnot the slightest joy in his heart when seated on Palestinian's throne. Joseph also did not moan when caught at the bottom of the well or into Egyptian prison and did not rejoice when appointed as the governor of Egypt. Imam Ali, the most unique person throughout the history, neither lament for losing his job as a ruler after the death of Prophet Muhammad, nor rejoice in getting his job back, because to him the government was worth a torn shoes.

\subsection{Behavior}

Acknowledging the certainty of human exposure to the difficulties in life, Quran teach appropriate behavior in dealing with it.

We shall test you with a bit of fear and hunger, plus a shortage of wealth and souls and produce. Announce such to patient people(2/155)

This patient treatment is rooted in this group's right attitude that is reflected in We belong to God, and are returning to Him!"( 2/156 )The faithful people see God as the owner and themselves as the property. The owner has the right to manipulate the property in any way he likes, therefore is patient in the best possible way. Such a person is not influenced by difficulties. (Tabatabai, Muhammad Hossein, 1417, vol. 1, p. 353)

The Quran uses the word "Ba" in this verse to refer to "the amount of" fear, hunger and loss in property that prepare the believers to endure the difficulties in the way of help to the prophet and make them aware that divine trials are not torturous. Patience is stated in many verses of the Qur'an as the only deed for which an incalculable reward is considered. (Zumar, 10)

Imam Sadiq quotes the Holy Prophet that: because the books will be opened and the deeds will be measured at doomsday, no balance is therefor those who suffered a lot of calamities and distress (Tabarsi, FazlibnHasan, Majma' alBayan, 1993, vol. 1, p. 435)

The patience (which is one of the virtues)does not imply that one is fallen under feet, stepped by other people and played with like a stone in front of the foot, because God has created man in such a way that bound himself by his nature to excrete every abomination. God has made him equipped with defending means and instruments in order to use them as much as possible. However, everything that invalidates and overrides the instinct cannot be called a virtue. The term patience implies that the man has in his heart an endurance that makes him able to control his sensual system, avert his heart from division and oblivion and avoid adverse thought and corruption. Therefore, the patients are those who endure suffering, are not succumbed by suffering and hardship, just unlike the impatients who become disappointed by the first adversity they encounter in their life and flee so that they do not look behind. (Tabatabai, Muhammad Hossein, 1417, vol. 11, p. 141)

In two verses of the Holy Quran, the word patience is accompanied with the adjective "beautiful" that has been interpreted as patience without any complaint. (Aroosi Huvayzi, 1415, vol. 2, p. 417)

However, the patience alone will not work and should be seasoned with trust in God. That is why Jacob mentions the help of God after referring to the beautiful patience. God is the One to seek help from against what you describe.( $12 / 18)$

Psychological coping strategies: Excitement is any kind of agitation or disturbance of mind, emotional feeling or any excited or powerful state of mind. By taking into consideration the combinations, variations, changes and minor discrepancies between them, the number of well-known emotions amounts to hundreds. Some of these emotions include anger, sadness, fear, happiness, love, surprise, disgust and shame. (Daniel Goleman, 2012, p. 388) This article will only discuss the control of sadness and happiness. Different people react differently tothe same event. Job loss, for example, can be interpreted in the following ways by different individuals: a situation that led to the loss of financial resources; a situation that endangers the social status; a situation that provides better job opportunities. Hence, the person treatment in the ongoing situation is very important. Lazarus and Folkman (1984) defines tress as a specific interaction between an individual and the environment in which the individual assesses the situation occurred. According to this view, the personal understanding and evaluation of the individual regulate the relationship between the difficult conditions and the individual state (emotional), not the objective characteristics of stressful situations. Therefore, it is necessary to distinguish the environmental factors that create stress from the mental effects of this situation. (Ahadi, Hassan., 2009, p. 45) Coping measures are thoughts and behaviors that are used once the person faced with stressful event, while coping resources are the personal properties of the person himself that exist before the outbreak of stress, such as having selfesteem, sense of control over the situation, cognitive styles, locus of control, self-efficacy and problem-solving ability. 
One of the most important issues in this regard is the individuals' assessment of their capabilities to deal with the issue. The assessments may or may not be in accordance with reality and the real capabilities of the person, however, the individual's perceptions of his strengths and capabilities are the principal determinants in dealing with the difficulties. If he feels he is unable to cope with problems successfully, he could not do so despite all the skills learned. Individuals assess their ability to deal with problems during three stages, which are very effective in the formation of coping strategies: Initial assessment: at this stage, the individual evaluates the predictors of stress and threat. For example, someone wonders whether the situation is threatening or not? Compatibility: at this stage he assesses his ability to do anything in relation to the stressful situations. In this case, one wonders what can be done to solve the ongoing problem. Second assessment: in the third stage, he reassesses the situation involved and asks whether his judgment of the positions or resources available to deal with the situation is correct. He regulates and reconstructs his behavior based on these assessments. (Ahadi, H., 2009, p. 42) Strategies of coping with excitement are divided into two groups: problem-oriented and excitement-oriented strategies.

Excitement-oriented strategies: Facing any stress will lead to a degree of confusion. The confusion strength varies from mild to very severe. Excitement-oriented strategies help human to obviate the emotion and excitement caused by exposure to stress. For example, when a person abandons his family and goes to another city, he may be sad for a while. Excitement-oriented strategies help such a person to overcome the grief. Seeking emotional support, crying, praying are some examples of these strategies.

Problem-oriented strategies: Problem-oriented strategies help to find out how to deal with stress. In this type of strategies, an activity should be done to remove or reduce or tolerate the stress. This strategy aims to reduce the pressures or discover alternatives to deal with them. Request for payment of past due accounts is a good example for this case. This model is applied by people when they believe they are able to do something in a stressful situation. Researches show that people are more likely to apply problem-focused coping strategies more than excitement-oriented ones and use excitement-oriented strategies in irreversible events such as death. Women are also more inclined to employ excitement-oriented strategies than men. (Billings and moose cited in M. Robin Dymatyv, 1999, vol. 2, p. 574), but often both approaches are needed to effectively cope with long-term difficulties. Although excitement-oriented efforts (emotion-oriented) do not deal with the facts and does not provide long-term solutions, the continuous effort to solve a problem without considering the psychological effects may put health at risk. Cognitivists propose the cognitive modification and restructuring techniques to deal with stress. Cognitions determine the ways to interpret events, their risks and their required compatibility. Perhaps the individual's reaction is more positive when he sees the change more exciting

and he thinks he is able to control it. Therefore, his stress level is lower than when he perceives the changes to be more awful and sees himself unable to control it. Examining the forced labor camps, Antonovsky came to the conclusion that some people, despite being in difficult situations ,have the mental strength to bear their problems without endangering their physical health. According to him, "sense of coherence" is a general resistance resource. general resistance resources are resources such as wealth, power, social protection, and the cultural strength that help the individual to save himself from the adverse effects of stress. Sense of coherence is to make the person sustainably and dynamically sure that:

1. The incentives arisen during the life from the internal and external environment are organized, predictable and justifiable.

2. The individual accesses to resources to deal with them.

3- The needs are challenges that are worth the investment and time. These people believed that, although some events, such as losing a job or the death of loved ones are not desirable to them, they could be understood. They explain the events in terms of certain physical forces, for example they attribute losing their jobs to their deprivation of important information or the war to the differences between the political forces. On the other hand, to them the world is tractable and things happen as logically expected. They know the life events as experiences with which we can cope. (Dymatyv, M. Robin, 1999, vol. 2, p. 587) Albert Ellis developed a method for changing the irrational cognitions. According to this approach, when people make irrational thought, stress assessment processes go wrong. Irrational beliefs may involve the disaster illusion. The other cognitive approach is stress inoculation which is based on the theory that if the person is cognitively prepared, he can reduce feelings of stress. Stress inoculation is performed through three stages of conceptualization (detailed analysis of stress experience), skills training and practice (relaxation techniques and desensitization) and the implementation and follow-up (change in behavior). (Dymatyv, M. Robin, 1999, vol. 2, p. 596) Another resource available to the person who is faced with the overwhelming event is social protection. Cognitive studies during the 1960s and 1970s showed that some psychosocial characteristics such as isolation increase the risk of social and psychological damage. Social support in the areas such as emotional support (expressed positive feelings and trust 
that create a sense of encouragement), respect support (Make the other people sure of an individual's competence and values), informative support (guidance, criticism, etc.) and material support (loans, financial assistance). To be satisfying for the receiver, the supports should have a specific and permanent source. (Ahadi, Hassan., 2009, p. 72)

\section{Analysis and Comparison}

Psychology focuses on the emotional control hrough social support on the one hand and problem solving on the other hand. More recently, the cognitivists have offered the changes in human attitudes as a strategy for dealing with the problems, but what is presented in Quran and hadith is divided into appropriate measures to control cognition, behavioral change and social support.

1. In the cognitive control dimension, 1. Islam seeks to train a human who understands that the suffering is an inherent part of the world (Balad, 3). This view has moderated human's expectations and trained the human in such a way that he is not shocked by the unpleasant events of his time.

2. Quran verses such as: My folk, this worldly life is to be enjoyed only[ briefly ]; the Hereafter is the Home to settle down in (40/39) and Worldly life is only a game and an amusement (47/36) inform the human that the life of this world is transient and limited andmake the acceptance and tolerance of difficulties easy for him. On the other hand, with the introduction of the Hereafter as the superior and eternal life whereas the Hereafter is better and more enduring (87/17), God makes him motivated to be patient in order to achieve a superior world.

3. That God manages the world by His wisdom and the tribulations of life may lead to human growth and contribute to a "good" of which he is unaware perhaps you dislike something in which God has placed much good ( 4/19)promotes his spiritual levels or provides an opportunity for him to better deal with the events.

4. That all human intentions and deeds influence his life and perhaps unpleasant incidents stem from human actions Any disaster that happens to you will[ occur ]because of what your own hands have earned (42/30) causes human to correct his deeds instead of being impatient and provides him the best.

\section{Supporting Measures}

1. The man trained by Quran does not see himself alone in the bittersweet events of his time He is with you( all )wherever you may be! God is Observant of anything you do. (57/4) He feels everywhere the powerful hand of God who is the most compassionate (and the most Merciful of Mercy-granter) 12/64) and the most closer to him (We are Closer to him than his jugular vein!( 50/16 )whose favor nobody can prevent and whose evil nobody can ward off (If God wanted[ to cause ]me any trouble, would such females ever remove His trouble? Or if He wants some mercy for me, will such females hold back His mercy?(49/38)) whose will is inviolable God will accomplish His purpose. God has granted everything in due proportion.( 65/3), and who suffices for human (Is not God Sufficient for His servant?(39/36). With permanent support of God with such characters, human must not feel insecure.

2. in addition to God's permanent support that is always an encouragement to the believer, the religious orders such as "'' (Believers merely form a brotherhood,(49/10) emphasis on kinship ties in more than 20 verses of Qur'an, including "*" (God commands justice, kindness and giving[ their due ]to near relatives (16/90), reference to Zakat and financial assistance to people alongside the prayer in more than 26 verses of Quran, introduction of the assistants of the large families of believers as the best people in the traditions of "the best of people is one who benefits the others '(Amoudi, Abdul Wahid, p. 357) and many such traditions make the hearts of believers closer in a way that the individuals trained by the religion would not neglect each other. With such a strong link, the believer will not see himself deprived of the social support of the others.

3. moderation in happiness: While acknowledging the need to encourage people to joy and happiness, Islam provides at first the opportunity for rational, stable and profound joy and secondly, avoid extreme happiness and provides grounds for moderation in it. Psychology also emphasizes the advantages of joy for the human spirit as an effective way to increase his happiness. However, no standard is devised for intellectual joy and nothing is said about preserving the moderation in happiness as well as maintaining the moral boundaries. What is posed in the science as indulgence in joy is «manic» disorder that completely differs from the boundary that Islam determines for happiness and joy. Mania is a type of mental illness that interferes with the person causing sudden changes in his behavior, mood, energy and ability to function. Patients with this disease are very active, lively, cheerful, with increased activity and self-important ideas in a period of their 
lives. Manic patients may have a strange sense of joy and they laugh and joke for no reason. They are laborious, but these activities are not limited to their job and they could be extraordinary active in the religious, social, educational affairs. Sometimes the hyperactivity of the manic patient leads to a decrease in his power. Rapid speech, decreased sleep, increased libido, reckless behavior, and noble ideas are of their characteristics. They may see their thoughts exquisite and their ideas important, or highlight their job. It may also happen that their noble intellectual background is turned to delirium and they believe that they are leaders with a mission to guide the authorities. (Purafkari, N., 1994, vol. 2, p. 873)

\section{Conclusions}

By examining what mentioned, it appears that:

1. Islamic educational school has offered appropriate strategies for the Muslim's cognitive restructuring to be able to deal with despairs. The strategies become possible only by accepting the existence of a wise Creator and clearly psychology could not achieve such amount of success in changing the attitudes.

2. The believer sees himself always supported by compassionate and omnipotent God and he does not feel loneliness and does not falter in the face of difficulties. Undoubtedly, such a powerful and compassionate support can't be comparable with the support outlined in the Psychology.

3. The human trained by Islam has a deep relationship with his brothers in faith; therefore he would possess the best and strongest social support in the face of difficulties. "Fraternity" and brotherhood among the believers proposed by Quran is the deepest relationship that provides the believer with the highest level of social support.

4. Since the believers attribute their success to the mercy of God, they would not be arrogant, preserve their mental balance in joy and success and do not get rebellious and proud. All the results could be complementary to the teachings of psychology.

\section{References}

Holy Quran translated by Irving, T . B.

Ahadi, Hassan, 2009, Health Psychology, AfshinRobati, Karaj, Sarafraz

Dashti, Muhammad, 1988, Nahjul-Balagha, Qom, Research Institute of Imam Ali

Dymatyv, M. Robin, 1999, Health Psychology, MuhammadKaviani et al., Tehran, Institute of Tehran University Press.

Ibn Babawayh, Muhammad Ibn Ali, 1413, Man la Yahduruhu al-Faqih, Ali Akbar Ghaffari, Qom, Qom Seminary Teachers Society.

Goleman, Daniel, 2001, Emotional Intelligence, NasrinParsa, Tehran, Roshd

JavadiAmoli, Abdullah, 1998, Morality in the Noble Qur'an, Qom, Asra.

JavadiAmoli, Abdullah, 2004, monotheism in Quran, Qom, Asra'.

IbnBabawayh, Muhammad IbnAli, 1999,UyunAkhbaral-Reza (AS), Mahdi, Lajavardi, Tehran, Jahan.

IbnShobehHarrani, Hassan Ben Ali, 1984, Tohaf al-Huqul, Ali Akbar Ghaffari, Qom, Qom Seminary Teachers Society.

Khomeini, Ruhollah, 1989, Forty Hadiths, Tehran, Raja'.

Kulaini, Muhammad bin Yaqoob, 1429, Usul al-Kafi, Qom, Dar al-Hadith

Tamimi Amoudi, Abdul Wahid ibn Muhammad, 1410, (Gorar Alhekam and Dorar Alkelam, revised by Seyyed Mehdi Rajai, Qom, Daralketab.

Purafkari, Nusratullah, 1994, the dictionary of psychology- psychiatry, Tehran, contemporary culture.

Majlesi, MuhammadBagher, 1403, Bihar al-Anwar, Beirut, Darahya'altrasArabi,

Modarresi, SeyyedMuhammadTaghi, 1419, Men Huda al- Quran, Tehran, dar al mohebalhosein

Motahari, Morteza., 1982, Divine Justice, Tehran, Sadra.

Tabarsi, FazlibnHasan, 1993, tafsir al-bayan, Tehran, NaserKhosro.

Tabatabai, MuhammadHossein, 1417, Tafsir al-mizan, Qom, Qom Seminary Teachers society

Tayeb, SeyedAbdolhossein, 1996, Atyab al-bayan fi tafsir al-Quran, Islamic publications.

Raghiblsfahani, Hussein bin Ahmad, n.d,Mufradat Alfaz Al- Quran, Beirut, Daralelm.

Zamakhshari, Mahmoud, 1407, AlkeshafAn Haghaegh GhavamezOI-Tanzil, Beirut, Dar alKitab al-Arab.

Zuhayli, Wahbabin Mustafa, 1418, Tafsir Al-MunirFil AqidahWasy-Syari'ahWalManhaj, Beirut, daralfekralmoaser. 